\title{
Assessment of drought tolerance of peanut cultivars based on physiological and yield traits in a semiarid environment
}

\author{
Jacqueline Wanessa de Lima Pereira ${ }^{a}$, Manoel Bandeira Albuquerque ${ }^{b}$, \\ Péricles Albuquerque Melo Filho ${ }^{a}$, Rejane Jurema Mansur Custódio Nogueira ${ }^{c}$, \\ Liziane Maria de Lima ${ }^{\mathrm{d}}$, Roseane Cavalcanti Santos ${ }^{\mathrm{d}, *}$ \\ a Universidade Federal Rural de Pernambuco/UFRPE, Departamento de Agronomia, Rua Dom Manoel de Medeiros, s/n, Dois Irmãos, Recife, Pernambuco, \\ Brazil \\ ${ }^{\mathrm{b}}$ Universidade Federal da Paraíba, Departamento de Fitotecnia e Ciências Ambientais, Centro de Ciências Agrárias, 231, 58397-000, Areia, Paraíba, Brazil \\ ${ }^{c}$ Universidade Federal Rural de Pernambuco/UFRPE, Departamento de Biologia, Rua Dom Manoel de Medeiros, s/n, Dois Irmãos, Recife, Pernambuco, Brazil \\ ' Empresa Brasileira de Pesquisa Agropecuária, Rua Oswaldo Cruz, 1143 Campina Grande, Paraíba, Brazil
}

\section{A R T I C L E I N F O}

\section{Article history:}

Received 13 April 2015

Received in revised form 7 December 2015

Accepted 12 December 2015

\section{Keywords:}

Arachis hypogaea L.

Stomata resistance

Semiarid adaptation

Breeding

\begin{abstract}
A B S T R A C T
The regular water supply during life cycle is essential to determine the yield in the legumes. In semiarid environments, the irregular rainfall and high temperature influence the phenology of crops impairing the yield. Peanut is an oleaginous crop with broad adaptation to tropical and semiarid climates, but yield is often harmed when plants face water irregularities during reproductive phase. The recommendation of cultivars tolerant to environments with water-limitation is indispensable to farmers in order to ensure reasonable production when drought settles down. Here, we evaluating peanut bred lines in order to assess drought tolerance based on physiological and yield traits, in greenhouse and field assays. In greenhouse experiment, 2 genotypes (BR 1, drought tolerant and the sensible LViPE-06) and 2 descendant bred lines (earliness-LBM Branco and a mid-runner, LBR Branco) were submitted to 21 days of total water supression. Diffusive resistance, transpiration and leaf water potential were measured by porometer (LI 1600), from fully expanded leaves at mid canopy. Root length was also measured at final period of water stress. Further, in a 2-year field experiment carried out in semiarid environment (Barbalha, CE, Brazil), the genotypes were evaluated under rainfed and irrigation, aiming to estimating the yield trait and the efficiency of drought tolerance. Physiological and yield traits of all genotypes were altered under water stress and significant responses were observed. Both top lines showed physiological ability to tolerance to drought, but LBM Branco, an earliness and upright line, was classified as drought tolerant showing behavior near to BR 1. The losses in pod and seed yield were low, comparing to runner parent (LViPE-06). LBR Branco showed an intermediary performance between parents and was classified as moderately tolerant. Based on physiological and agronomic performances, LBM Branco can later be recommended for management in semiarid environment.
\end{abstract}

(c) 2015 Elsevier B.V. All rights reserved.

\section{Introduction}

Drought stress has been the major environmental factor responsible to yield losses in several crops worldwide. The losses are highly variable depending on timing, intensity, and duration coupled with other location-specific environmental stress factors such

\footnotetext{
* Corresponding author. Fax: +55 8331824367.

E-mail addresses: jacquelinewlp@gmail.com (J.W. de Lima Pereira), manoel@cca.ufpb.br (M.B. Albuquerque), periclesmf@gmail.com (P.A. Melo Filho), rjmansur1@gmail.com (R.J. Mansur Custódio Nogueira), liziane.lima@embrapa.br (L.M. de Lima), roseane.santos@embrapa.br (R.C. Santos).
}

as high irradiance, temperature and salinity (Graciano et al., 2011; Kambiranda et al., 2011). At cell level, drought often leads to devastating effects in plant metabolism, with direct actions in thylakoid electron transport, phosphorylation and carboxylation (Bhagsari et al., 1976; Lauriano et al., 2000). The membrane permeability and solute synthesis are increased in water-stressed plants, leading to membrane disruption as well as reduction in photosynthesis, depending on stress level.

Plants have several mechanisms for adaptation to water stress including stomatal conductance and osmotic adjustments. The combination of these traits, associated with lower oxidative damage in cells will reflect in the adaptive response of the plant to 
survive in situations of extended drought (Azevedo Neto et al., 2009; Clavel et al., 2004; Nogueira et al., 2006). Understanding physiological and molecular genetics may lead to the understanding of stress response and aid in development of new varieties with stress tolerance.

Breeding for drought tolerance has been an important strategy adopted by researchers to alleviate the water stress problems and to ensure the production in environments prone to drought (Pereira et al., 2012; Santos et al., 2013; Songsri et al., 2008). However, the inheritance of characters associated with drought adaptation is likely to be genetically complex, due to the number and arrangement of genes governing quantitative traits (Leal-Bertioli et al., 2012). Researchers have attempted to improve performance by selecting plants with good yield under drought conditions in order to enable stability of production.

The selection of plants with ability to extract water from the soil is an additional procedure to aid to genetic improvement to drought tolerance. Deep rooting, root length density and root distribution are adaptive traits often adopted as selection criteria for drought resistance (Benjamin and Nielsen, 2006; Matsui and Singh, 2003; Taiz and Zeiger, 2006 Yusuf Ali et al., 2005). According to Rucker et al. (1995), large root system may improve the plant's ability to continue growth during a drought period.

Peanut (Arachis hypogaea L.) is an important oleaginous food, widely cultivated in tropical and semiarid regions, where drought is one of the most limiting factors for production. In environments where water availability is deficent, upright cultivars represent an important alternative to farmers due to short cycle and low water requirement during the growth (Painawadee et al., 2009; Vorasoot et al., 2003). However, even grown under irrigation, peanut may experience drought because of limited water supply or because irrigation water is applied in amounts or at frequencies that are less than optimal for plant growth, especially during pod and seed filling (Awal and Ikeda, 2002; Pereira et al., 2012; Songsri et al., 2008).

According to Azevedo Neto et al. (2009), who evaluated several physiological and biochemical traits in interspecific genotypes of Arachis submitted to moderate water stress, the osmotic adjustment and the activity of antioxidant enzymes are more effective in tolerant plants, as a response to avoiding major damage to cell metabolism. Jain et al. (2001) identified several up-and down-regulated transcripts associated with water stress in waterstressed peanut plants, all of them exhibiting qualitative and quantitative differences in the gene expression.

In agronomical aspect, the criteria for selection of peanutdrought resistance are often based on biomass production and pod yield under water stress conditions (Duarte et al., 2013; Santos et al., 2010). Drought-stressed plants lose moisture from pods that can lead to reduction in physiological activity of the seeds and consequentially affecting both yield and nutritional quality (Songsri et al., 2008).

In a correlation study carried out by Songsri et al. (2008) involving traits associated to drought tolerance and pod production, authors found high magnitude correlations among drought tolerance index (DTI), pod yield, root length density (RLD) and harvest index (HI), indicating that RLD in deeper soil contributed to pod yield and $\mathrm{HI}$ under drought conditions. This association is quite relevant to peanut because pods have underground growth and the adequate moisture in root zone is critical for peg and pod development. Water deficit in the pegging and root zones can decrease pod and seed productions in approximately 30\% (Kambiranda et al., 2011).

The Brazilian Company of Agricultural Research (EMBRAPA) coordinates a robust program of peanut improvement focused on northeast semiarid environment. This region is characterized by soils of low fertility, erratic rainfall and moderate veranicos that occur in rainy season. Periodically, several intra and interspecific lines are generated by crossings for further use in selection procedures in order to identifying high yield and drought tolerant materials. The selection criteria are based on biochemical, physiological and agronomic traits. In 2012, a bulk of 20 intraspecific lines was evaluated in field condition in order to selecting earliness and high yield materials for further recommendation to food markets situated in Northeast region. Two top lines were selected showing pod yield $23 \%$ higher than the average of population. In this work, we report about these materials, evaluated during two years in order to determine the effects of moderate drought on yield based on physiological and agronomical traits.

\section{Material and methods}

\subsection{Water stress assay in greenhouse}

Seeds of four peanut genotypes ( 2 bred lines and parents) were grown in greenhouse and submitted to moderate water stress. Experiment was carried out at the Agricultural Department of Federal Rural University of Pernambuco, Brazil, located in Recife, PE $\left(08^{\circ} 03^{\prime} 14^{\prime \prime} \mathrm{S}, 34^{\circ} 52^{\prime} 52^{\prime \prime} \mathrm{W}, 4 \mathrm{~m}\right)$. A summarized description of each genotype is presented: BR 1 ( $A$. hypogaea subsp. fastigiata, ), is an earliness and drought tolerant-upright cultivar developed by EMBRAPA to semiarid environment (Graciano et al., 2011; Santos et al., 1999, 2013); LViPE-06 (A. hypogaea subsp. hypogaea, $\sigma^{7}$ ) is a high yield- runner genotype and sensible to drought (Santos et al., 2013), LBM-06 and LBR-06 are, respectively, an upright-short cycle and a runner-mid cycle top lines, both generated by crossing between BR1 $\times$ LViPE-06.

The experimental procedure was carried out according to Azevedo Neto et al. (2009). Four seeds of each genotypes were sown in pots $(10 \mathrm{~L})$ containing sandy-loam texture soil previously limed and fertilized (NPK, 20:60:30, ammonium sulfate, single superphosphate and potassium chloride). Fourteen days after emergence, seedling were thinned to two per pot. The watering (100\% field capacity) was daily until seedlings aged 20 days, when water treatments were established: control (100\% field capacity) and water stress (total withdrawal of water during 21 days). Field capacity was determined by gravimetric method after $72 \mathrm{~h}$ of draining. The pots of both treatments were weighed daily and, in the control treatment, the water lost by transpiration was replaced. In order to prevent the losses by evaporation, soil surface of each pot was covered with polyethylene discs. A completely randomized design with bi-factorial scheme was adopted $(4 \times 2)$, with 10 replications. Leaf temperature, air relative humidity and photosynthetic active radiation (at noon) data were recorded at 1,2 and 3 weeks of water stress establishment (Table 1 ).

\subsection{Physiological traits}

Diffusive resistance (Rs), transpiration (T) and leaf water potential $\left(\Psi_{\mathrm{w}}\right)$ were periodically evaluated on abaxial and adaxial

\section{Table 1}

Data collected in greenhouse by steady-state porometer LI-1600, during water stress establishment.

\begin{tabular}{|c|c|c|c|c|c|c|c|c|c|}
\hline \multirow[b]{2}{*}{ Genotype } & \multirow[b]{2}{*}{ LT } & \multicolumn{3}{|l|}{$1 \mathrm{w}$} & \multicolumn{3}{|l|}{$2 w$} & \multicolumn{2}{|l|}{$3 w$} \\
\hline & & $\mathrm{RH}$ & PAR & LT & $\mathrm{RH}$ & PAR & LT & RH & PAR \\
\hline BR1 & 32.7 & 49.9 & 507.6 & 31.9 & 52.1 & 558.1 & 33.9 & 50.8 & 754.4 \\
\hline LViPE-06 & 31.3 & 51.9 & 558.7 & 33.9 & 55.7 & 747.3 & 32.0 & 60.6 & 368.9 \\
\hline LBM Branco & 33.7 & 51.9 & 434.8 & 33.9 & 53.4 & 625.7 & 34.3 & 50.5 & 670.7 \\
\hline LBR-Branco & 32.7 & 54.7 & 647.6 & 33.4 & 47.9 & 591.9 & 33.6 & 49.3 & 507.0 \\
\hline
\end{tabular}

w-week of water stress, LT- leaf temperature $\left({ }^{\circ} \mathrm{C}\right), \mathrm{RH}$-relative humidity of air (\%), PAR- photosynthetically active radiation $\left(\mu \mathrm{mol} . \mathrm{m}^{-2} \mathrm{~s}^{-1}\right)$. 
A)

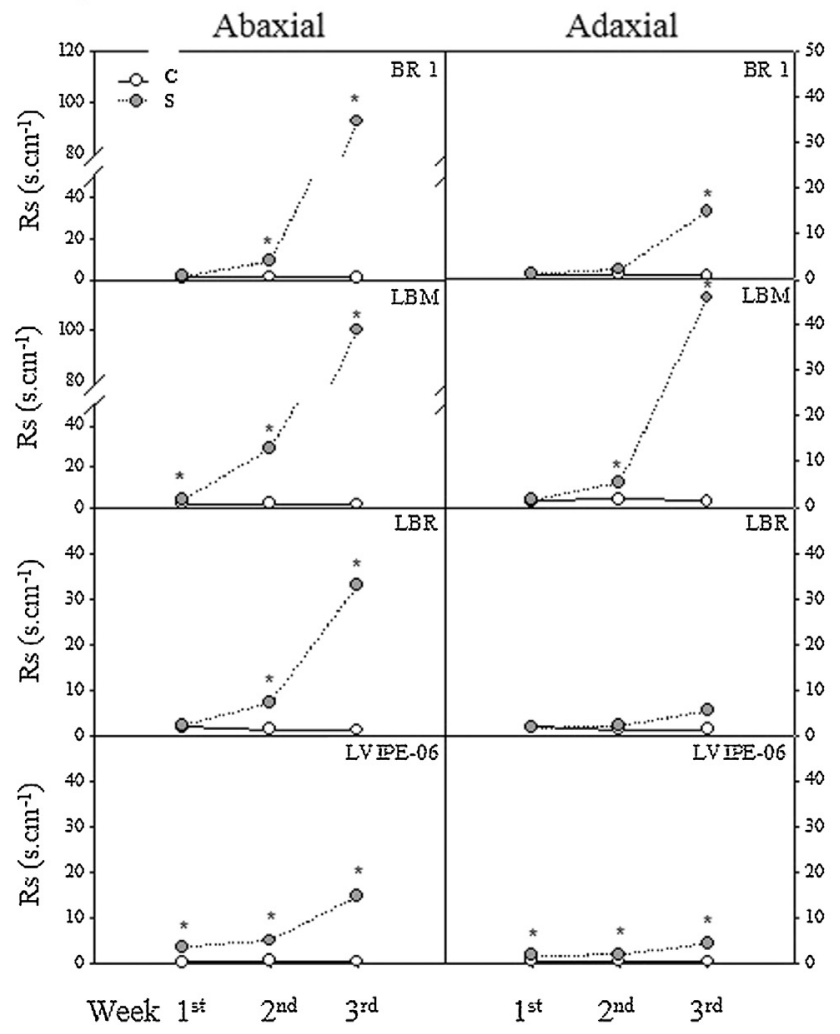

B)

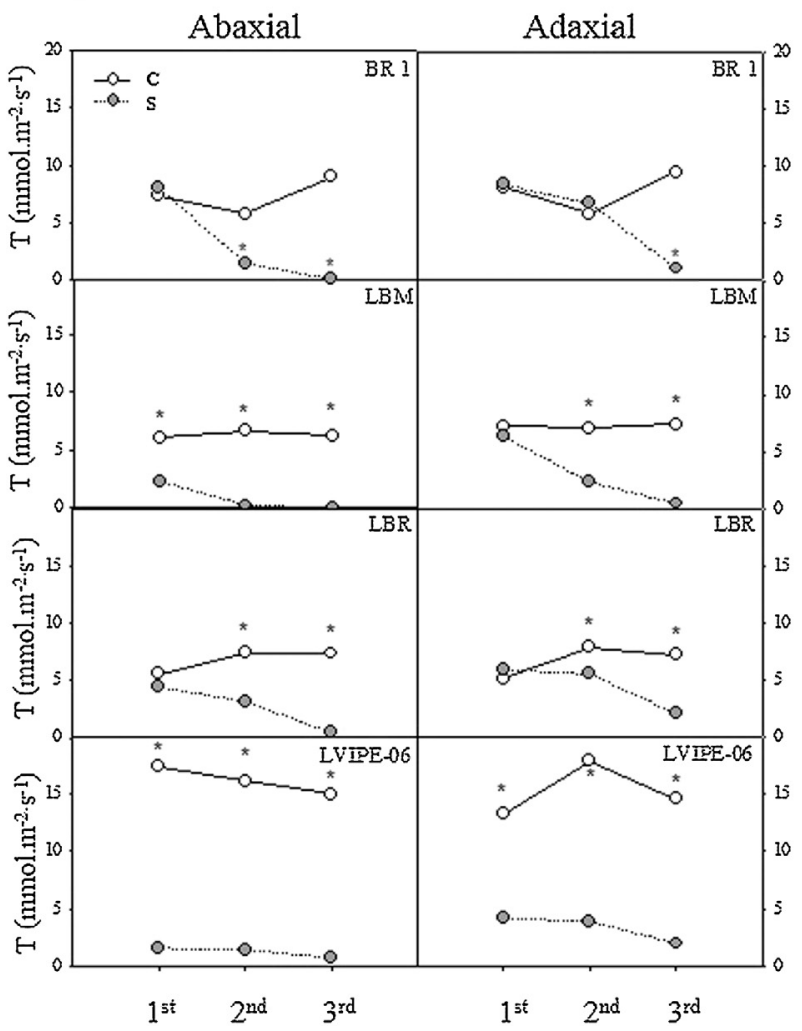

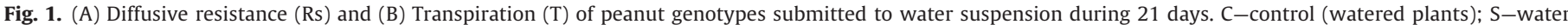
stressed treatment. $\left({ }^{*}\right)$ Indicates statistical difference between treatments $(p<0.05)$

surfaces of fully expanded leaves at mid canopy in both treatments, at 9-11 a.m. A steady-state porometer, model LI-1600 (LI-COR, Inc Lincoln, NE, USA) was used for Rs and E estimating. The leaf water potential $\left(\Psi_{\mathrm{w}}\right)$ was obtained by using a pressure chamber, model 3030 (Soil Moisture Equipment Corp, Santa Barbara, CA, USA).

\subsection{Root lengths}

This trait was recorded in all genotypes at harvest of plants. Root samples of each pot were carefully washed manually on a wire mesh screen with tap water to remove soil and debris. Root length was measured at physiological maturity, that took place at 85-90 d to upright genotypes and $115-120 \mathrm{~d}$ to runner materials (Santos et al., 2009). Data were recorded from two plants of each pot, using the average for further statistical analysis.

\subsection{Field assay}

A 2-year experiment (2013 and 2014) was carried out at Experimental Field of EMBRAPA (Brazilian Company of Agricultural Research), in Barbalha, CE (07 $18^{\prime} 18^{\prime \prime S}$; 39 $\left.{ }^{\circ} 8^{\prime} 07^{\prime \prime} \mathrm{W}, 414 \mathrm{~m}\right)$, located in warm semiarid of Brazilian Northeast, with average of annual rainfall of $986 \mathrm{~m}$, concentrated between December and April, and annual evaporation of $2625 \mathrm{~mm}$ (Silva and Amaral, 2008).

Trials were carried out during the dry (Jul-Nov) and rainy (Dec-Apr) seasons. Temperature, relative humidity of air and precipitation data were collected from weather station located $1000 \mathrm{~m}$ from experimental field. During peanut cycle the rainfed was $395 \mathrm{~mm}$ in 2013 and $406 \mathrm{~mm}$ in 2014, while in the dry season had no interference from rain. The seasonal mean maximum and minimum air temperature ranged between $30^{\circ} \mathrm{C}$ and $34^{\circ} \mathrm{C}$, during $2013 / 14$.
The experiments were carried out in a clay loam-Vertisoil, previously limed (dolomitic lime, 2 tha ${ }^{1}$ ) and fertilized NPK, 20:60:30, ammonium sulfate, single superphosphate and potassium chloride, prior to planting. The physical and fertility traits of soil in depth of $0-30 \mathrm{~cm}$ are: fine sand $-30.82 \%$, silt $-38.67 \%$, clay $-30.51 \%$, apparent density $-1.29 \mathrm{~g} \mathrm{~cm}^{-3}$, real density $-2.65 \mathrm{~g} \mathrm{~cm}^{-3}$, porosity $-51.32 \%$ and available water 13.27 (Silva and Amaral, 2008).

Genotypes were grown under rainfed and irrigated conditions aiming to estimating the yield traits and the efficiency of tolerance to drought, following methodology reported in Arunachalam and Kannan (2013) and Ndunguru et al. (1995). Seeds were sown in 3 rows of $5 \mathrm{~m}$ length, spaced in $70 \mathrm{~cm} \times 20 \mathrm{~cm}$ in a randomized complete block design with five replications. Four seeds were planted per hill and the seedlings were thinned to two plants per hill at 5 days after emergence. The experiment was surrounded by guard rows to avoid damage and boarder effects. The crop was grown by adopting recommended package of practices, described in Santos et al. (2006).

The calculations of the water requirements to peanut crop during dry season were estimated based on atmospheric demand in Barbalha (CE), and on coefficient of water consumption by peanut, descripted in Barreto and Luz (2006). The demand estimated to peanut crop was $680 \mathrm{~mm}$, considering the soil texture and profile of $0.25 \mathrm{~m}$ to field capacity. The efficiency of application of water in conventional sprinkler irrigation system under field conditions was 0.7 .

After harvest, the observations recorded were pod and seed yield, harvest index (HI) and drought tolerance efficiency (DTE). HI was estimated by pod yield/total biomass production ratio, based on dry weight of the plants (Painawadee et al., 2009). DTE was estimated by ratio of pod yield obtained in rainy/irrigated seasons, as 
suggested in Fischer and Wood (1981). According to authors, genotypes with high value of DTE are considered as drought tolerant.

\subsection{Statistical analysis}

Physiological and agronomic data were subjected to variance analysis by using SAS software (SAS Institute, 1999). Homogeneity of variance was previously tested for all traits. Tukey test $(p \leq 0,05)$ was used to comparing means.

\section{Results and discussion}

\subsection{Physiological behavior of bred lines}

Different changes in stomata behavior were verified in all genotypes due to effect of water stress. In general, diffusive resistance (Rs) obtained from control plants was relatively low and stable during all period of evaluation, while in water-stressed genotypes Rs was increased soon at 1 st week in LBM-Branco (abaxial surfaces) and LViPE-06 (abaxial and adaxial surfaces) (Fig. 1A). From the 2nd week on, Rs increased in all water-stressed genotypes from abaxial surface, mainly LBM-Branco. This line also showed increased Rs in adaxial surface and full stomata closure from the 3rd week.

In water-stressed plants, the response of Rs is signaled by stomata closure in order to prevent water losses during dry conditions. Changes in ostiole size leads to several alterations on photosynthesis and transpiration rates, and to variations in gas conductance. According to Taiz and Zeiger (2006), a temporary closing of stomata due to water deficit is considered a modular adaptation, which could prevent water supplying in tissues during the dry season. In the present study, the differential response of Rs suggests that LBM-Branco and LViPE-06 detected earlier the water deficit around rhizosphere zone and prevented the loss of water minimizing the transpiration. Such behavior can contribute to save water and keep longer the water status of tissues. However, others physiological strategies are necessary to increase the water uptake in order to avoid changes in mesophyll conductance and consequently, further reduction on photosynthesis rate.

The values obtained to transpiration $(\mathrm{T})$ in control and waterstressed plants are shown in Fig. 1B. T-rates were expressively altered in genotypes, at first in LViPE-06 (both leaf surfaces), soon on the 1 st week. From the 2nd on, all genotypes showed severe reductions in both surfaces, excepting to BR 1 , that declined only in the abaxial surface. Also from 2nd week, changes in the leaf water potential $\left(\Psi_{\mathrm{w}}\right)$ were verified in stressed plants, at first in LBMBranco and LBR-Branco (Fig. 2), both expressing lower levels of $\Psi_{\mathrm{w}}$ $(-2.10$ and $-1.33 \mathrm{MPa}$, respectively). At 21 days, these values were more negative ( -2.93 and $-1.88 \mathrm{MPa}$ respectively), overcoming the drought-tolerant cv. BR $1(-1.78 \mathrm{MPa})$. These results are relevant because $\mathrm{cv}$. BR 1 has been a comparative material often used for tolerance to drought and adaptation to the semiarid environment experiments. In severe-water stress assays, Nogueira and Santos (2000), found very low value of $\Psi_{\mathrm{w}}(-5.35 \mathrm{MPa})$ to BR 1 submitted to 45 days water suppression. It was considered the most tolerant to drought and further confirmed as highly adapted to semiarid region, based on several field experiments (Gomes et al., 2007; Santos et al., 2010).

The effects of physiological changes seen here in peanut genotypes submitted to drought have been reported in literature. Subramaniam and Maheswari (1990) reported that leaf water potential and transpiration rate decreased progressively with increasing duration of water stress indicating that plants under mild stress were postponing tissue dehydration. Few days of water deficit stress induce a rapid increase in the stomatal resistance that in turn reduces transpiration and net photosynthesis due to
Table 2

Root length of peanut genotypes submitted to water suspension during 21 days.

\begin{tabular}{llll}
\hline Genotype & $\begin{array}{l}\text { Root length }(\mathrm{cm}) \\
\mathrm{C}\end{array}$ & $\mathrm{S}$ & $\begin{array}{l}\text { RD } \\
(\%)\end{array}$ \\
\hline BR1 & $32.7 \mathrm{Bb}$ & $38.9 \mathrm{Ba}$ & +19 \\
LViPE-06 & $44.7 \mathrm{Aa}$ & $32.7 \mathrm{Bb}$ & -27 \\
LBM-Branco & $40.4 \mathrm{ABb}$ & $45.8 \mathrm{Aa}$ & +13 \\
LBR-Branco & $44.2 \mathrm{Aa}$ & $38.1 \mathrm{Bb}$ & -14
\end{tabular}

C: control; S: water stress; RD: relative difference based on control treatment; Means followed by the same letter are not significantly different (Tukey test, $p \leq 0.05$ ). Capital letter compares between genotypes and lowercase between treatments.

stomatal closure (Takele and McDavid, 1995). Under severe dry conditions, the leaf area and leaf weight of the plants decrease due to reduction on nitrogen-binding activity of root nodules. In tolerant plants, the mechanisms adopted to drought tolerance are maintenance of turgor through osmotic adjustment, increased cell elasticity and decreased cell size as well as desiccation tolerance by protoplasmic resistance (Nemeskeri et al., 2012).

The ability of peanut to recover from prolonged desiccation has been reported. According Babu and Rao (1983), the threshold for stomatal closure due to moisture stress is about $-1.35 \mathrm{MPa}$ of leaf water potential. The stomata characteristics (amphistomatous) contribute to drought adaptation, whose situated in adaxial side are more responsive to drought stress (Nogueira et al., 2006).

\subsection{Root length}

The averages of root length obtained from peanut genotypes submitted to 21 days of water stress are shown in Table 2. The upright materials (BR 1 and LBM Branco) showed best ability to expanding their roots under water stress treatment (19\% and 13\%, respectively) than LBR Branco that had $14 \%$ of reduction. More reduced growth was seen to LViPE-06 (27\%), indicating that in the period evaluated in this work, water stress affected drastically the root performance in runner genotypes. These results confirm the ability of Valencia types (upright, A. hypogaea subsp. fastigiata) to deep rooting in soils with low water availability, in order to tolerate the water stress condition (Vorasoot et al., 2003). The ability to shorten the flowering cycle is other strategy of water stress-tolerant plants and has been adopted as selection criteria in breeding program to drought resistance in peanut (Santos et al., 2013a).

Water stress often stimulates the growth of roots into deeper soil. The capacity to modify the root traits, especially root length, by exploiting the available of water in deeper soil represents an important mechanism to avoid drought and ensure plant survivals (Kambiranda et al., 2011; Rucker et al., 1995; Songsri et al., 2008). In peanut, the ability to maintain a viable root system during water stress may contribute to the crop's drought resistance (Sanders et al., 1993). This behavior does not guarantee high yield but avoid larger losses in environments with limited moisture availability. During water stress, roots in lower depths continue to grow deeper in tolerant plants. In well-watered condition, Ketring and Reid (1993), found that peanut roots at 40-45 days had penetrated to a depth of $120 \mathrm{~cm}$ and spread laterally at least $46 \mathrm{~cm}$. In fine sand soil, roots can reach $180 \mathrm{~cm}$ (Allen et al., 1976). The moisture balance in the root systems ensures the productivity in several crops. According Nemeskéri et al. (2012), during short-term drought intensive root elongation to the deeper part of the soil profile and the partial or total stomatal closure provide the avoidance of water loss for the plants. Even mild water stress can reduce the rate of leaf area development leading to lower photosynthetic activity and low amount of produced biomass. 


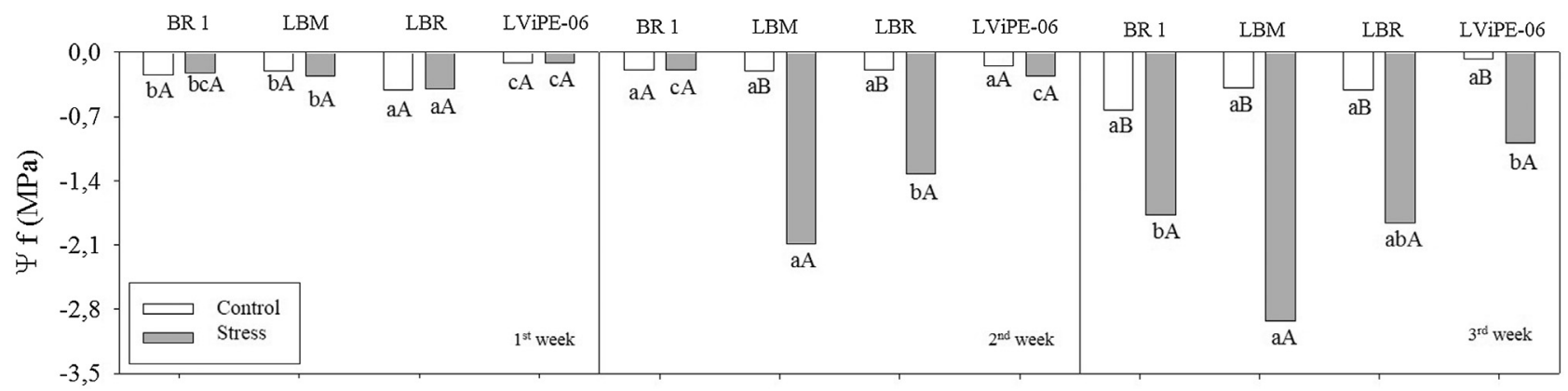

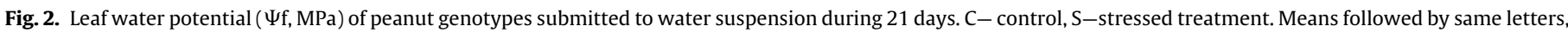
uppercase between water treatments and lowercase among genotypes, not statistically different by Tukey test $(P<0.05)$.

\subsection{Agronomical traits}

The combined means of yield traits and DTE of peanut genotypes grown in rainy and irrigated conditions during two years are found in Table 3. The total volume of water provided to peanut crop during rainy and irrigated conditions promoted differences in pod and seed productions and in HI, which were expressively higher in irrigated crop, mainly to runner genotypes. During both experimental year, about $58 \%$ of total volume of rain fallen in the first two months of peanut crop, impairing the phenology due to distribution and irregularity of rains (Fig. 3). The late LViPE-06 was more sensitive to water irregularity established in rainy condition, showing reduction in pod and seed yield next to $55 \%$. This reduction affected the $\mathrm{HI}$ that was decreased to $31 \%$. The performance of BR 1 and LBM Branco were statically similar, showing $32 \%$ and $41 \%$ of losses in pod and seed yield, respectively, comparing to production obtained in irrigated condition. As to LBR Branco, although is a runner type, demonstrated ability to ensure production in rainy condition, revealing a performance next to its earliness genitor, BR 1.

The ability of both top lines to adjustment of assimilates in rainy season, in order to promote the growth of aerial part and pod sets was also confirmed by the values of $\mathrm{HI}$, which were reduced in only $16 \%$ and $13 \%$ in LBM Branco and LBR Branco, respectively, comparing to irrigated management. These results were favored because the start of flowering was not delayed by drought stress in these lines, although a reduction in the daily emission of flowers was seen in all genotypes (data not shown). According to Gowda and Hegde (1986), when stress is imposed during 30-45 days after sowing the first flush of flowers produced up to 45 days do not form pegs during this time, however, flowers produced after re-watering compensated the losses.

The values of DTE, which index identifying genotypes that maintain adequate yield under water deficit conditions (Clavel et al., 2006), revealed that upright-LBM Branco had drought tolerance behavior (see value obtained to tolerant BR 1) and LBR Branco was drought-moderate, confirming results obtained by Pereira et al (2012).

The results obtained here for the upright genotypes are consistent with those obtained in literature (Duarte et al., 2013; Gomes et al., 2007; Pereira et al., 2015). BR 1 is a drought tolerant cultivar and LBM Branco is a BR 1-derivative line, which inherited the traits of earliness and tolerance to drought. However, a quite interesting result was seen to performance of LBR Branco, a mid cycle-runner type, with traits of drought adaptation and pod sets inherited from the earliness BR 1 and the high-yield LViPE-06. According to Pereira et al. (2012), who submitted LBR Branco to moderate water stress, this line is mid-tolerant to drought and shows satisfactory ability to adjust osmotically in water deficit condition. Based on physiological and agronomical traits, LBR Branco could represent a promising material to semiarid condition and an opportunity for further recommendations of runner cultivars to Brazilian Northeast region.

Drought stress has been the major environmental factor contributing to the reduced agricultural productivity and food safety worldwide. The resistance to drought is a very desired trait in breeding programs but it is also a complex process because drought triggers various molecular events in plants, leading to different responses in sensitive and resistant genotypes. According to Lauriano et al. (2000), drought stress perceived by the plant from its surrounding environment varies spatially and temporally at several different scales, affecting membrane lipids and photosynthetic responses, such as thylakoid electron transport, phosphorylation and carboxylation. The consequences of these changes are reflected in the performance of crops, because as they have different genetic adjustments, they respond phenotypically to stress facilitating the selection.

Understanding physiological and molecular genetics may lead to aid in development of new cultivars with stress tolerance. Therefore, the identification of resistant materials based on single aspects may not be very effective because it can lead to misinterpretation and prejudicing the selection of really promising materials.

Table 3

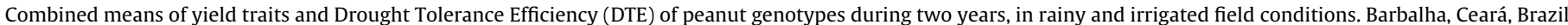
(2013/14)

\begin{tabular}{|c|c|c|c|c|c|c|c|c|c|c|}
\hline & $\begin{array}{l}\text { Pod yield } \\
\left(\text { tha }^{-1}\right)\end{array}$ & & RD & $\begin{array}{l}\text { Seed yield } \\
\left(\text { tha }^{-1}\right)\end{array}$ & $\mathrm{RD}$ & & $\mathrm{HI}$ & & $\mathrm{RD}$ & DTE \\
\hline Genotype & I & $\mathrm{R}$ & & I & $\mathrm{R}$ & & I & $\mathrm{R}$ & & \\
\hline BR 1 & $2.6 \mathrm{Ab}$ & $1.8 \mathrm{Bb}$ & 31 & $1.9 \mathrm{Ab}$ & $1.1 \mathrm{Bb}$ & 42 & $40.8 \mathrm{Ab}$ & 31.9Bc & 22 & $0.70 \mathrm{a}$ \\
\hline LBM Branco & $2.5 \mathrm{Ab}$ & $1.7 \mathrm{Bb}$ & 32 & $1.8 \mathrm{Ab}$ & $1.1 \mathrm{Bb}$ & 39 & $42.2 \mathrm{Ab}$ & $35.5 \mathrm{Bb}$ & 16 & $0.68 a$ \\
\hline Mean & 2.6 & 1.8 & & 1.9 & 1.1 & & 41.5 & 33.7 & & 0.69 \\
\hline LViPE-06 & $4.5 \mathrm{Aa}$ & 2.0Bab & 56 & $2.9 \mathrm{Aa}$ & 1.3Ba & 55 & 46.8Aa & $32.4 \mathrm{Bc}$ & 31 & $0.44 \mathrm{c}$ \\
\hline LBR Branco & 3.56Aab & $2.1 \mathrm{Ba}$ & 31 & $2.6 \mathrm{Aa}$ & $1.4 \mathrm{Ba}$ & 46 & 45.9Aa & $39.8 \mathrm{Ba}$ & 13 & $0.58 \mathrm{~b}$ \\
\hline Mean & 4.1 & 2.3 & & 2.8 & 1.4 & & 46.3 & 36.1 & & 0.53 \\
\hline
\end{tabular}

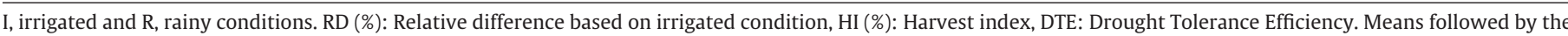
same letter are not significantly different at Tukey test $(p \leq 0.05)$. Capital letter compares between treatment and minuscule, between genotypes. 
Babu, V.R., Rao, D.V.M., 1983. Water stress adaptations in the groundnut (Arachis hypogaea L.)- foliar characteristics and adaptations to moisture stress. Plant Physiol. Biochem. 10, 64-80.

Barreto, A.N., Luz, M.J.S., 2006. Procedimentos de cálculo para a quantificação da necessidade hídrica e do suprimento de água à cultura do amendoim no município de Barbalha-CE. Comunicado técnico. Edited by Embrapa. Campina Grande 284, 1-4.

Benjamin, J.G., Nielsen, D.C., 2006. Water deficit effects on root distribution of soybean, field pea and chickpea. Field Crops Res. 97, 248-253.

Bhagsari, A.S., Brown, R.H., Schepers, J.S., 1976. Effect of moisture stress on photosynthesis and some related physiological characteristics in peanuts. CropScience 16, 712-715.

Clavel, D., Sarr, B., Marone, E., Ortiz, R., 2004. Potential agronomic and physiological traits of Spanish groundnut varieties (Arachis hypogaea L.) as selection criteria under end-of-cycle drought conditions. Agron. Sustain. Dev. 24, 101-111.

Clavel, D., Diouf, O., Khalfaoui, J.L., Braconnier, S., 2006. Genotypes variations in fluorescence parameters among closely related groundnut (Arachis hypogaea L.) lines and their potential for drought screening programs. Field Crops Res. 96, 296-306

Duarte, E.A.A., Melo Filho, P.A., Santos, R.C., 2013. Características agronômicas e índice de colheita de diferentes genótipos de amendoim submetidos a estresse hídrico. Revista Brasileira de Engenharia Agrícola e Ambiental 17, 843-847.

Fischer, K.S., Wood, G., 1981. Breeding and selection for drought tolerance in tropical maize. In: In: Proc. Symp. On Principles and Methods in Crop Import. Drought is Resist. With Emphasis on Rice, IRRI, Philippines, May 23-25th.

Gomes, L.R., Santos, R.C., Anunciação Filho, C.J., Melo Filho, P.A., 2007. Adaptabilidade e estabilidade fenotípica de genótipos de amendoim de porte ereto. Pesquisa Agropecuária Brasileira 42, 985-989.

Gowda, A., Hegde, B.R., 1986. Moisture stress and hormonal influence on the flowering behaviour of groundnut (Arachis hypogaea L.). Madras Agric. J. 73, 82-86.

Graciano, E.S.A., Nogueira, R.J.M.C., Lima, D.R.M., Pacheco, C.M., Santos, R.C., 2011. Crescimento e capacidade fotossintética da cultivar de amendoim BR $1 \mathrm{sob}$ condições de salinidade. Revista Brasileira de Engenharia Agrícola e Ambiental $15,794-800$

Jain, A.K., Basha, S.M., Holbrook, C.C., 2001. Identification of drought-responsive transcripts in peanut (Arachis hypogaea L.). J. Biotechnol. 4, 59-67.

Kambiranda, D.M., Vasanthaiah, H.K.N., Ananga, R.K.A., Basha, S.M., Naik, K., 2011 Impact of drought stress on peanut (Arachis hypogaea L.). In: Productivity and Food Safety. Plants and Environment, Edited by InTech, pp. 249-272.

Ketring, D.L., Reid, J.L., 1993. Growth and peanut roots under field conditions. Agron. J. 85, 80-85.

Lauriano, J.A., Lidon, F.C., Carvalho, C.A., Campos, P.S., Matos, M.D.C., 2000. Drought effects on membrane lipids and photosynthetic activity in different peanut cultivars. Photosynthetica 38, 7-12.

Leal-Bertioli, S.C.M., Bertioli, D.J., Guimarães, P.M., Pereira, T.D., Galhardo, I., Silva, J.P., Brasileiro, A.B.M., Oliveira, R.S., Silva, P.I.T., Vadez, V., Araújo, A.C.G., 2012. The effect of tetraploidization of wild Arachis on leaf morphology and other drought-related traits. Environ. Exp. Bot. 84, 17-24.

Matsui, T., Singh, B.B., 2003. Root characteristics in cowpea related to drought tolerance at the seedling stage. Exp. Agric. 39, 29-38.

Ndunguru, B.J., Ntare, B.R., Williams, J.H., Greenberg, D.C., 1995. Assessment of groundnut cultivars for end-of-season drought tolerance in a Sahelian environment. J. Agric. Sci. 125, 79-85.
Nemeskéri, E., Molnar, K., Víg, R., Dobos, A., Nagy, J., 2012. Defence strategies of annual plants against drought. In: Montanaro, I. (Ed.), Advances in Selected Plant Physiology Aspects. InTech., Croatia, p. 388.

Nogueira, R.J.M.C., Santos, R.C., 2000. Alterações fisiológicas no amendoim submetido ao estresse hídrico. Revista Brasileira de Engenharia Agrícola e Ambiental 4, 41-45.

Nogueira, R.J.M.C., Melo Filho, P.A., Carvalho, R., Albuquerque, M.B., Santos, R.C., 2006. Comportamento estomático e potencial da água da folha em amendoim cv Brs 15117 submetido a estresse hídrico. Revista Brasileira de Oleaginosas e Fibrosas 10, 985-991.

Painawadee, M., Jogloy, S., Kesmala, T., Akkasaeng, C., Patanothai, A., 2009. Identification of traits related to drought resistance in Peanut (Arachis hypogaea L.). Asian J. Plant Sci. 8, 120-128.

Pereira, J.W.L., Melo Filho, P.A., Albuquerque, M.B., Nogueira, R.J.M.C., Santos, R.C., 2012. Mudanças bioquímicas em genótipos de amendoim submetidos a déficit hídrico moderado. Revista Ciência Agronômica 43, 766-773.

Rucker, K.S., Kvien, C.K., Holbrook, C.C., Hook, J.E., 1995. Identification of peanut genotypes with improved drought avoidance traits. Peanut Sci. 21, 14-18.

Sanders, T.H., Cole, R.J., Balnkenship, P.D., Dorner, J.W., 1993. Aflatoxin contamination of peanuts from plants drought stressed in pod and root zones. Peanut Sci. 20, 5-8.

Pereira, J.W.L., Silva, E.C.A., Luz, L.N., Nogueira, R.J.M.C., Melo Filho, P.A., Lima, L.M., Santos, R.C., 2015. Cluster analysis to select peanut drought tolerance lines. Aust. J. Crop Sci. 9 (11), 1095-1105.

Santos, R.C., Farias, F.J.C., Rêgo, G.M., Silva, A.P.G., Ferreira Filho, J.R., Vasconcelos, O.L., Coutinho, J.L.B., 1999. Estabilidade fenotípica de cultivares de amendoim avaliadas na região Nordeste do Brasil. Ciência e Agrotecnologia 23, 808-812.

Santos, R.C., Rego, G.M., Santos, C.A., Melo Filho, P.A., Silva, A.P.G., Gondim, T.M.S. Suassuna, T.F., 2006. Recomendações técnicas para o cultivo do amendoim. Circular técnica. Embrapa. Campina Grande 102, 1-7.

Santos, R.C., Rêgo, M.G., Silva, A.P.G., Vasconcelos, J.O.L., Coutinho, J.L.B., Melo Filho, P.A., 2010. Produtividade de linhagens avançadas de amendoim em condições de sequeiro no Nordeste brasileiro Revista Brasileira de Engenharia Agrícola e Ambiental. Campina Grande-PB 14, 589-593.

Santos, R.C., Queiroz, C.M., Batista, V.G.L., Silva, C.R.C., Pinheiro, M.P.N., Galvão Filho, A.L.A., Melo Filho, P.A., Lima, L.M., 2013. Variabilidade de progênies F2 de amendoim geradas por meio de seleção de genitores ISSR-divergentes. Revista Ciência Agronômica 44, 578-586b.

Songsri, P., Jogloy, S., Vorasoot, N., Akkasaeng, C., Patanothai, A., Holbrook, C.C., 2008. Root distribution of drought-resistant peanut genotypes. J. Agron. Crop Sci. 194, 92-103.

Subramaniam, V.B., Maheswari, M., 1990. Physiological responses of groundnut to water stress. Indian J. Plant Physiol. 33, 130-135.

L. Taiz E. Zeiger Stress physiology In: Plant Physiology, 4th edition, Edited by Sinauer Associates, Inc., Sunde MA 2006 671-681.

Takele, A., McDavid, C.R., 1995. The response of pigeonpea cultivars to short durations of waterlogging. Afr. Crops Sci. J. 3, 51-58.

Vorasoot, N., Songsri, P., Akkasaeng, C., Jogloy, S., Patanothai, A., 2003. Effect of water stress on yield and agronomic characters of peanut (Arachis hypogaea L.) Songklanakarin J. Sci. Technol. 25, 283-288.

Yusuf Ali, M., Johansen, C., Krishnamurthy, L., Hamid, A., 2005. Genotypic variation in root systems of chickpea (Cicer arietinum L.) across environments. J. Agron. Crop Sci. 191, 464-472. 